\title{
Kimble v. Marvel Entertainment, LLC: Economic Efficiency Caught in the Web of Improper Judicial Restraint
}

Maxwell C. McGraw*

\section{INTRODUCTION}

"Innovation that excites."1 "Think different." "Progress through Technology." Every day, consumers encounter flashy corporate slogans as companies compete to catch their attention - and their dollar. In today's innovative business climate the development and retention of intellectual property (IP) has emerged as a significant driver of economic success. According to the Global Intellectual Property Center, an affiliate of the U.S. Chamber of Commerce, IP-intensive industries drive $74 \%$ of all United States exports (approximately $\$ 1$ trillion), ${ }^{4}$ and corporations spend approximately $\$ 420$ billion in research and development each year. ${ }^{5}$

Patents are an incredibly valuable intellectual property asset, and they are not developed exclusively by large corporations. From the labs of a biotechnology company to the research and development department of a tech start-up to a flash of brilliance in a Midwestern garage, the next big idea

* J.D. Candidate, 2017, University of Kansas School of Law; B.S. Civil Engineering, 2011, University of Kansas. I would like to thank Dr. Andrew Torrance for his helpful feedback and guidance throughout the writing process, as well as Klint Spiller and the members of the University of Kansas Law Review for their hard work and assistance in publishing this Note. I would also like to thank my family and friends for their constant encouragement and support. Most importantly, thank you to my fiancé Kara for her unbounded patience during the entire law school process, and for still agreeing to marry me. Finally, thank you to the 2015 World Series Champion Kansas City Royals whose on-field heroics provided me with the extra burst of energy needed to complete this Note.

1. NisSAN, http://www.nissanusa.com (last visited Sept. 23, 2016).

2. Apple Steve Jobs the Crazy Ones, YouTuBE (Feb. 1, 2009), https://www.youtube.com/watch?v=8rwsuXHA7RA.

3. About Audi, AUDI OF AMERICA, https://www.audiusa.com/about (last visited Sept. 23, 2016).

4. Nam D. Pham, IP Creates Jobs for America, Global Intell. Prop. Ctr. 2, http://image.uschamber.com/lib/fee913797d6303/m/1/IP+Creates+Jobs+-

+Executive+Summary+Web+-+2013.pdf.

5. The Global Intellectual Property Center estimates the amount of money spent on research and development in each state. This figure represents the aggregate amount spent in all states. Employing Innovation Across America, GlOBAL INTELL. PROP. CTR., http://www.theglobalipcenter.com/ip-employs-innovation (last visited Sept. 23, 2016). 
could come from anywhere at any time. After obtaining a patent, a common way to monetize the invention is through a patent licensing agreement.

Many agreements include a royalty payment arrangement for the sale of products developed from the licensed patent. In patent law, a patent grants the owner the right to exclude others from making, using, or selling the patented technology. ${ }^{6}$ The owner possesses this power of exclusion for a statutory proscribed period (usually twenty years). ${ }^{7}$ However, after the statutory period has run, the use of the patented technology is released to the public. Granting patent rights incentivize inventors to innovate, and the statutory limit ensures a limited monopoly power. Antitrust concerns arise when a royalty arrangement continues in perpetuity beyond the expiration of the patent. The seminal case regarding the legality of post-expiration royalties ${ }^{8}$ in patent licensing agreements is Brulotte v. Thys Co. ${ }^{9}$ In Brulotte, the Court held that post-expiration royalties were illegal per se due to the antitrust concern of extending the patent monopoly beyond its proscribed period. $^{10}$

Although the Brulotte decision received both judicial and industry criticism, the Supreme Court recently upheld the holding in Kimble v. Marvel Entertainment, LLC. ${ }^{11}$ In Kimble, the plaintiff, Stephen Kimble, licensed a patent to Marvel for what eventually became the Spider-Man Web Blaster toy. ${ }^{12}$ The plaintiff received an approximately $\$ 500,000$ lump sum payment along with an agreement to receive 3\% royalties for future sales of the toy, ${ }^{13}$ but no mention was made as to when the royalty payments would end. ${ }^{14}$ Marvel later became aware of the Brulotte decision and ceased payments to the plaintiff following the expiration of his patent. ${ }^{15}$ Ultimately, the Supreme Court found the Brulotte decision to be an exercise of statutory interpretation, upheld the per se ban under the doctrine of stare decisis, and directed critics of the ban to seek relief from Congress. ${ }^{16}$ The Supreme Court's analysis in Kimble was incorrect because the Brulotte Court based

\footnotetext{
6. $\quad$ See U.S. CONST. art. $1, \S 8$, cl. 8 .

7. See 35 U.S.C. $\S 154($ a), (c) (Supp. 2014).

8. Post-expiration patent royalties are royalties paid to the licensor after the patent term has expired on the patent.

9. Brulotte v. Thys Co., 379 U.S. 29 (1964).

10. Id. at 32-34.

11. Kimble v. Marvel Entm't, LLC, 135 S. Ct. 2401 (2015).

12. Id. at $2405-06$.

13. Marvel Entm't, 135 S. Ct. at 2406; Kimble v. Marvel Enters., 727 F.3d 856, 858-59 (9th Cir. 2013).

14. Marvel Entm't, 135 S. Ct. at 2406

15. Id.

16. Id. at $2414-15$.
} 
its ruling on antitrust concerns, not a statutory construction of the patent laws. Upholding the per se ban on post-expiration royalties grossly intrudes on a patent holder's freedom to contract, and is based on faulty economic theory. As a result of this ruling, companies and individuals have two options when entering into long-term patent licensing agreements: (1) contract around the per se ban on post-expiration patent royalties or (2) pursue a new federal statute that overrules the Court's decision. Continuously contracting around the per se ban is an economically inefficient option that could ultimately lead to important technological developments never making it to market. Therefore, Congress should enact a new federal statute to govern patent licensing agreements that include postexpiration royalties.

Part II of this Note will discuss the background of the United States patent system and the bodies of law governing patent licensing agreements. Part II will also discuss the development of case law concerning postexpiration royalties, and will examine the reasoning behind the Supreme Court's decision in Kimble v. Marvel Entertainment, LLC. Part III will outline the problems with the Court's analysis in Kimble and the policy implications of upholding a per se ban on post-expiration royalties, and will propose a federal statute to instruct the courts how to evaluate the legality of such agreements. Developing such a policy will abandon the unworkable and economically inefficient per se ban on post-expiration royalties while respecting the antitrust sentiments ingrained within the United States patent system.

\section{BACKGROUND}

\section{A. Development of the United States Patent System}

Earlier civilizations referenced patent-like rights, and the Venetian Senate developed the first patent system resembling our current law in the late fifteenth century with the 1474 Act. $^{17}$ Because of the spread of trade, Italian merchants introduced the concept of patent protection to the rest of Europe. ${ }^{18}$ In the sixteenth century, Great Britain eventually began to recognize these patent rights as an incentive for foreign inventors to bring their new technologies and skills to England. ${ }^{19}$

17. Robert P. Merges et al., Intellectual Property in the NeW Technological Age 123-24 (Vicki Been et al. eds., 6th ed. 2012) ("The term 'patent'-from the Latin patere (to be open), referring to an open letter of privilege from the sovereign — originated in this period.").

18. Id. at 124 .

19. Id. 
By the early seventeenth century, under Elizabeth I, the common law established that the crown should decide when to grant patent monopoly rights for inventions. ${ }^{20}$ Conditions were imposed upon inventors who wished to receive patents for their inventions. ${ }^{21}$ James I continued this practice, but a perception that the king gave preferential treatment to his companions and advisors led to a host of complaints. ${ }^{22}$ Both inventions and particular industries obtained patent rights in England. ${ }^{23}$

Members of Parliament operated within many of the industries selectively granted patent rights, which resulted in injuries to their businesses, ${ }^{24}$ and the public became increasingly outraged over the "odious monopolies. $" 25$ In response, Parliament passed the Statute of Monopolies in 1624, which directed the courts "to review all privileges granted by the crown and outlaw[] all but those based on true inventions."26 By passing this piece of legislation, Parliament recognized patent rights in a limited sense for the purpose of encouraging innovation and balanced antitrust concerns with economic incentives. ${ }^{27}$

The establishment of the American colonies brought with it British common law legal traditions, including patent law. ${ }^{28}$ Originally, the individual states issued patents, which led to numerous conflicts. ${ }^{29}$ In order to quell the increasing litigation, the Constitutional Convention of 1789 included a discussion regarding the creation of a United States patent system. ${ }^{30}$ The Framers ultimately included a provision in Article 1, Section 8 of the United States Constitution to authorize Congress " $[t]$ o promote the Progress of Science and useful Arts, by securing for limited Times to Authors and Inventors the exclusive Right to their respective Writings and Discoveries." ${ }^{\prime 31}$ This marked the beginning of a patent system in the United

20. Edward C. Walterscheid, The Early Evolution of the United States Patent Law: Antecedents (Part 2), 76 J. PAT. \& TRADEMARK OFF. SOC'Y 849, 852-54, 870 (1994) ("The term 'invention' meant the establishment of a new trade or industry, either through importation or through actual discovery of new technology.").

21. Id. at 870-71 (Novelty was required, "but only in the sense that the 'invention' had not been worked in England within living memory.").

22. MERGES ET AL., supra note 17, at 124.

23. Id. "Running ale-houses" were an example of an industry given preferential treatment. $I d$.

24. $I d$.

25. Walterscheid, supra note 20 , at 872.

26. MERGES ET AL., supra note 17, at 124-25.

27. Id. at 125 .

28. Id.

29. Id. One notable disagreement between states centered around steamboat patents. Id.

30. Id. at $125-26$.

31. U.S. CONST. art. $1, \S 8$, cl. 8. 
States that has undergone numerous changes through the years. ${ }^{32}$

Under current United States Patent and Trademark Office (USPTO) regulations, so long as the inventor meets all the statutory requirements, ${ }^{33}$ he or she obtains an exclusive right to exclude others from using, making, or selling the patented invention for an express statutory period. ${ }^{34}$ Once the statutory period has run, the invention is released to the public and free to use. $^{35}$

\section{B. Patent Licensing Agreements}

When an inventor is granted a patent by the Patent and Trademark Office (PTO), he or she has the right to exclude "any subsequent developer, including a completely independent inventor, from using the same invention ...."36 Some inventors do not wish (or do not have the financial resources) to develop, market and sell their technology or inventions themselves, and must instead confer their rights to another party by way of an exclusive or non-exclusive license. ${ }^{37}$ Such agreements incorporate principles of patent law, contract law, and antitrust law. ${ }^{38}$

32. Thomas Jefferson was one of the key drafters of the original patent statute in 1790, which was the first draft of patent laws in the United States. MERGES ET AL., supra note 17, at 126. The 1790 Act was "substituted for the pro forma registration system of the 1793 Act." Id. In the midnineteenth century, the patent system was changed to include "what is now called nonobviousness" as another requirement for patentability. Id. The next major revision was the 1952 Patent Act, which enforced the favorability of patentability after "the nation threw all available resources into the war effort, [and] the armed forces called on engineers and scientists to perfect a vast array of new technologies in short order." Id. at 127. The Leahy-Smith America Invents Act was the next major patent law reform, and was signed into law by President Barack Obama in 2011. See Leahy-Smith America Invents Act Implementation, UnITED STATES PAT. \& TRADEMARK OfF., https://www.uspto.gov/patent/laws-and-regulations/leahy-smith-america-invents-act-implementation (last visited Oct. 21, 2016).

33. Statutory requirements for patentability include utility, novelty, nonobviousness, and enablement. 35 U.S.C. $\S \S 101-103,112$ (2012).

34. See 35 U.S.C. $§ 154(a),(c)$ (Supp. 2014).

35. Id.

36. Roger M. Milgrim \& ERic E. Bensen, Milgrim on Licensing § 1.01 (Matthew Bender, rev. ed. 2016).

37. JAY DRATLER, JR., LiCENSING OF INTELLECTUAL PROPERTY § 1A.01 (2016) (“[W]hether a license is exclusive or nonexclusive is one of the most important scope terms. Only if the license is nonexclusive can the licensor make more money by selling precisely the same thing-a nonexclusive license of the same rights in the same subject matter-to multiple parties. If the license is exclusive, the licensor can multiply its revenue streams only by limiting each license, for example, to a specified field of use.").

38. Id. (" $[\mathrm{T}]$ he explosion in commercial exploitation and licensing of intellectual property since the 1970s has begun to produce a body of what might loosely be called the contract law of licensing.”). 


\section{Patent Assignment vs. Patent License}

Patent agreements can be viewed as one of two distinct forms of contracts: assignments or licenses. ${ }^{39}$ When a transferor assigns a patent to another individual or corporation he or she "gives the transferee the right to sue for infringement, since title to the whole or undivided part of the patent is deemed to have passed." 40 The Supreme Court case Waterman $v$. Mackenzie summarized the difference between an assignment and a license:

The patentee or his assigns may, by instrument in writing, assign, grant, and convey, either (1) the whole patent, comprising the exclusive right to make, use, and vend the invention throughout the United States; or (2) an undivided part or share of that exclusive right; or (3) the exclusive right under the patent within and throughout a specified part of the United States. A transfer of either of these three kinds of interests is an assignment, properly speaking, and vests in the assignee a title in so much of the patent itself, with a right to sue infringers. In the second case, jointly with the assignor. In the first and third cases, in the name of the assignee alone. Any assignment or transfer, short of one of these, is a mere license, giving the licensee no title in the patent, and no right to sue at law in his own name for an infringement.

In Kimble, the case at issue in this Note, the question was not whether the patent agreement was an assignment or license. ${ }^{42}$ If Kimble and Marvel constructed an assignment agreement, Marvel would have purchased the full rights to the patent with no continuing obligation to pay Kimble. The agreement, instead, tethered Kimble and Marvel together by including "running royalties," thus "tak[ing] on some relational aspect" distinctive of a licensing agreement. ${ }^{43}$

\section{Controlling Law Governing Patent Licensing Agreements}

While state law usually governs contractual agreements, patent licensing

39. Harold Einhorn \& Eric E. Bensen, Patent Licensing Transactions $\S 1.01$ (Matthew Bender, rev. ed. 2016).

40. Id. at $\S 1.01(1)(\mathrm{b})$.

41. Waterman v. Mackenzie, 138 U.S. 252, 255 (1891) (citations omitted).

42. See generally Kimble v. Marvel Entm't, LLC, 135 S. Ct. 2401 (2015).

43. EINHORN \& BENSEN, supra note 39, at § 1.01 ("A simple single payment assignment is, for example, a transactional contract. However, when a license is entered into with running royalties, the contract takes on some relational aspect since there is a continuing reporting and payment relationship. Even more relational is a license with running royalties and a continuing flow of improvements. There is in fact a spectrum in licenses from simple transactional agreements to those which are highly relational (such as joint research agreements).”). 
agreements are controlled by relevant federal law. ${ }^{44}$ Patent licensing agreements that extend beyond the scope of the patent expiration date are the focus of this Note. As such, these types of agreements have antitrust law considerations and express statutory provisions governing patent expiration, ${ }^{45}$ which puts them firmly in the federal realm. ${ }^{46}$

The pertinent patent law principles center on the expiration of the licensed patent. As noted above, there are express statutory provisions that govern the lifetime of a patent. ${ }^{47}$ Utility $^{48}$ and plant ${ }^{49}$ patents are generally granted a patent term of twenty years, while design patents ${ }^{50}$ are granted a shorter term of fifteen years. ${ }^{51}$ While there are certainly more patent law conflicts that may arise within licensing agreements (infringement, validity, etc.), the scope of this Note does not bring them into focus.

\section{Patents \& Antitrust Concerns}

A patent is a monopoly granted to the inventor for a statutorily defined period of time, and "the mere acquisition of patent rights" through a patent licensing agreement does not invoke antitrust violations. ${ }^{52}$ Once the patent expires, it is released to the public for all to use, thus terminating the monopoly. ${ }^{53}$ Antitrust considerations heavily influence patent licensing transactions as well as the United States patent law system as a whole. The original concern and distrust of antitrust activity led to the Statute of Monopolies, ${ }^{54}$ and the United States echoed similar antitrust sentiments with the Sherman Act in $18900^{55}$ The Sherman Act was "the first modern

44. DRATLER, supra note 37, at $\S 1$ A.02 ("[T]he Supremacy Clause of the United States Constitution lets federal law trump state law whenever the two conflict.").

45. See supra notes 31-35.

46. DRATLER, supra note 37 , at $\S 1 \mathrm{~A} .02$ ("The broadest field in which supervening federal policy imparts licensing agreements as such is that of federal antitrust law ....”).

47. See supra notes 33-35 and accompanying text.

48. A utility patent is a patent granted for an invention that is a "process, machine, manufacture, or composition of matter . ..." 35 U.S.C. $\S 101$ (2012).

49. Plant patents are available for the invention or discovery of a new and distinct variety of asexually reproducing plants. 35 U.S.C. $\S 161$ (2012).

50. A design patent is a patent granted for a "new, original and ornamental design for an article of manufacture ...." 35 U.S.C. $§ 171$ (2012).

51. 35 U.S.C. $\$ 173$ (2012).

52. EINHORN \& BENSEN, supra note 39 , at $\S 7.01$.

53. DRATLER, supra note 37 , at $\S 6.02$ (citations omitted) ("Patents were exempted from the original Statute of Monopolies, just as they are excluded from antitrust scrutiny today, for one reason only. They encourage the innovation that fuels the fires of competition and enriches the public domain once the patents expire. The exemption of patents as good monopolies thus encourages development of products and processes that are ultimately superadded to the common store.").

54. See supra notes 24-29 and accompanying text.

55. DRATLER, supra note 37 , at $\S 5.02$. 
antitrust statute... [and] laid the foundation for all of antitrust... law today. $" 56$ It is considered unique due to its brevity relative to other United States statutes, with its interpretation delegated largely to the courts. ${ }^{57}$ The major components of the Sherman Act expressly condemn both the restraint of trade ${ }^{58}$ and monopolies. ${ }^{59}$

While the Sherman Act was an effort to restrict monopolization and encourage competition, its provisions do not explicitly instruct "what conduct is permitted and what is not." States ... is largely judge-made law." ${ }^{, 1}$ The courts raise these antitrust concerns when royalty provisions in the patent licensing agreement extend beyond the expiration date of the patent, and, as a result, have looked unfavorably upon such agreements.

\section{Per Se Ban of Post-Expiration Royalties}

\section{Early Decisions}

The issue of post-expiration royalties in patent licensing agreements is a relatively recent development. ${ }^{62}$ The first appearance of the issue was in Scott Paper Co. v. Marcalus Manufacturing Co., when Chief Justice Stone wrote, "any attempted reservation or continuation in the patentee or those claiming under him of the patent monopoly, after the patent expires, whatever the legal device employed, runs counter to the policy and purpose of the patent laws." ${ }^{63}$ The Third Circuit followed similar reasoning in 1959. In American Securit Co. v. Shatterproof Glass Corp. ${ }^{64}$ the court held that it was patent abuse for a multi-patent license agreement to include a provision that continued royalty payments until all patents in the agreement expired. ${ }^{65}$

The Third Circuit revisited this reasoning in 1962 in a case that involved a patent license containing a single patent. In Ar-Tik Systems, Inc. v. Dairy Queen, Inc., the plaintiff entered into a patent licensing agreement with the

\footnotetext{
56. Id.

57. Id.

58. 15 U.S.C. $\S 1$ (2012) ("Every contract, combination in the form of trust or otherwise, or conspiracy, in restraint of trade ... is declared to be illegal.").

59. Id. $\S 2$ ("Every person who shall monopolize, or attempt to monopolize ... any part of the trade or commerce among the several States ... shall be deemed guilty of a felony .....").

60. DRATLER, supra note 37 , at $\S 5.02$.

61. Id.

62. EINHORN \& BENSEN, supra note 39, at $§ 7.06$.

63. Scott Paper Co. v. Marcalus Mfg. Co., 326 U.S. 249, 256 (1945).

64. Am. Securit Co. v. Shatterproof Glass Corp., 268 F.2d 769 (3d Cir. 1959).

65. Id. at 777 .
} 
defendant to allow the defendant "to use and to permit others to use [the plaintiff's patented] frozen dessert machine. ${ }^{, 66}$ Utilizing the Supreme Court's language in Scott Paper Co. and the Third Circuit's holding American Securit Co., the court held that the "patent monopoly was spent" upon expiration of the patent in question and that "[a]n attempt to extend that monopoly by the exaction of royalties thereafter was unenforceable." Post-expiration patent royalties invoked significant antitrust concerns in these early court decisions, concerns that ultimately made their way to the Supreme Court.

\section{Supreme Court Precedent}

The issue of post-expiration patent royalties, and the Third Circuit's reasoning for its ban, was first reviewed by the Supreme Court in Brulotte $v$. Thys Co. ${ }^{68}$ In Brulotte, the plaintiff, Thys Company, licensed to the defendants, multiple hop farmers, a hop-picking machine that incorporated seven of the plaintiff's patents for a specified royalty structure. ${ }^{69}$ Even though all of the patents expired by 1957, the licensing agreement provided for continued royalty payments. ${ }^{70}$ The plaintiff brought suit for the defendants' refusal to adhere to the contractually agreed upon royalty structure "both before and after the expiration of the patents.", The Supreme Court adopted similar reasoning as the preceding cases, and Justice Douglas highlighted significant antitrust concerns:

[W]e conclude that a patentee's use of a royalty agreement that projects beyond the expiration date of the patent is unlawful per se. If that device were available to patentees, the free market visualized for the post-expiration period would be subject to monopoly influences that have no proper place there.

$\ldots$

A patent empowers the owner to exact royalties as high as he can negotiate with the leverage of that monopoly. But to use that leverage to project those royalty payments beyond the life of the patent is

\footnotetext{
66. Ar-Tik Sys., Inc. v. Dairy Queen, Inc., 302 F.2d 496, 497 (3d Cir. 1962).

67. Id. at 510 .

68. EINHORN \& BENSEN, supra note 39, at § 7.06.

69. Brulotte v. Thys Co., 379 U.S. 29, 29-30 (1964) ("Under that license there is payable a minimum royalty of $\$ 500$ for each hop-picking season or $\$ 3.331 / 3$ per 200 pounds of dried hops harvested by the machine, whichever is greater.").

70. Id. at 30 .

71. Id.
} 
analogous to an effort to enlarge the monopoly of the patent by tieing ${ }^{72}$ [sic] the sale or use of the patented article to the purchase or use of unpatented ones.

Keeping in line with anti-monopoly motivations, the decision in Brulotte established a per se ban on post-expiration royalties in patent licensing agreements. ${ }^{74}$

For licensing agreements that involve a single patent, this per se rule is straightforward: no patent royalties beyond the expiration date of the patent. However, many licensing agreements can include a large number of patents - especially in the medical and biotech research fields. Following the Brulotte decision, circuit courts heard cases on the issue of patent licensing agreements that encompass multiple patents, and held that "the law regarding post-expiration royalties [in this case] is in a fluid state." 75 The lower courts ultimately have affirmed the Brulotte decision, though not without significant criticism. ${ }^{76}$

72. "A seller's agreement to sell one product or service only if the buyer also buys a different product or service; a seller's refusal to sell one product or service unless the buyer also buys a different product or service.” Tying Arrangement, BLACK's LAW DICTIONARY (10th ed. 2014).

73. Brulotte, 379 U.S. at 32-33 (emphasis added).

74. Id.

75. EINHORN \& BENSEN, supra note 39, at $§ 7.06$.

In view of the foregoing discussion of the most recent cases in point, however, the following conclusions may be drawn:

(1) A patent owner should make no license agreement, even though a potential licensee is willing, under which the royalty for a single patent is payable beyond its expiration date or under which the royalty for a group of patents is payable beyond the expiration date of the last to expire.

(2) Special precautions must be taken whenever a patent owner enters a license agreement in which one or more, but not all, patents will expire during the license term. At the very least, coercion should be avoided. Perhaps the safest procedure following the expiration of a key licensed patent is to give the licensee the right to terminate the agreement and the option to take a license at a reasonable, negotiated royalty on the unexpired patents which remain.

(3) Alternatively, the licensor should consider offering a package wherein the licensee pays a major proportion of the royalty rate for the first patent, and then increasing amounts for the second, third, or more patents under which he desires to operate. The licensor should not condition the grant of a patent license upon payment of royalties on products that do not use the teaching. Conditioning consists of a patentee's insistence on a percentage-of-sales royalty, regardless of use, and his rejection of licensee proposals to pay only for actual use. In order to find conditioning under a "total sales" provision, a patent licensor must have (1) insisted upon or demanded the payment of royalties on merchandise which the licensor clearly knew did not employ the discovery which the Id. claims of the patent define and (2) rejected licensee proposals to pay only for actual use.

76. $I d$. 


\section{Criticism of Brulotte}

The Seventh Circuit Court of Appeals, specifically Judge Posner, has been critical of the reasoning in Brulotte. $^{77}$ In USM Corp. v. SPS Technologies, Inc., Judge Posner was skeptical that post-expiration royalties extended a patent holder's patent rights. ${ }^{78}$ Specifically, he wrote:

one might question whether any of these practices really "extends" the patent. The patentee who insists on limiting the freedom of his purchaser or licensee-whether to price, to use complimentary inputs of the purchaser's choice, or to make competing items - will have to compensate the purchaser for the restriction by charging a lower price for the use of the patent.

Judge Posner revisited this issue in detail in $2002 .^{80}$

In Scheiber v. Dolby Laboratories, Inc., the defendant, Dolby Laboratories, cited Brulotte's decision as its main argument for halting payment of royalties for any patents in the agreement beyond their expiration date. ${ }^{81}$ Finding Brulotte to be on point, Judge Posner began by noting the ample criticism Brulotte has received. ${ }^{82}$ He disagreed with the finding that post-expiration royalties "extends the patent beyond the term fixed in the patent statute . ... 83 Judge Posner noted that the goal of patent expiration was to end the right of the patent holder to exclude others from using the patent, and wrote that in licensing agreements "[a]fter the patent expires, anyone can make the patented process or product without being guilty of patent infringement.... Expiration thus accomplishes what it is supposed to accomplish." ${ }^{\prime 4}$ Judge Posner acknowledged that criticism of the Brulotte decision would be unwarranted if the decision resulted from construction of the Article 1, Section 8 provision of the Constitution or a patent statute, but noted instead that the decision "seem[ed] rather to have been a free-floating product of a misplaced fear of monopoly ... that was not even tied to one of the antitrust statutes." ${ }^{~} 5$ While Judge Posner clearly

\footnotetext{
77. See USM Corp. v. SPS Techs., Inc., 694 F.2d 505, 510-11 (7th Cir. 1982). See also Scheiber v. Dolby Labs., Inc., 293 F.3d 1014, 1017-19 (7th Cir. 2002).

78. USM Corp., 694 F.2d at 510-11.

79. Id.

80. Scheiber, 293 F.3d at 1014

81. Id. at $1016-17$.

82. Id. at 1017 ("[Brulotte] has, it is true, been severely, and as it seems to us, with all due respect, justly, criticized ....").

83. Id.

84. Id.

85. Id. at 1018 (citations omitted).
} 
disagreed with the Brulotte reasoning, ${ }^{86}$ he explained that the doctrine of stare decisis prevented the court from overturning the decision. ${ }^{87}$

Outside of the court system, contemporary commentators have also criticized Brulotte as a decision based upon an unfounded fear of patent monopoly extension:

The Brulotte rule incorrectly assumes that a patent license has significance after the patent terminates. When the patent term ends, the exclusive right to make, use or sell the licensed invention also ends. Because the invention is available to the world, the license in fact ceases to have value. Presumably, licensees know this when they enter into a licensing agreement. If the licensing agreement calls for royalty payments beyond the patent term, the parties base those payments on the licensees' assessment of the value of the license during the patent period. These payments, therefore, do not represent an extension in time of the patent monopoly.

$\cdots$

... Courts do not remove the obligation of the consignee to pay because payment after receipt is an extension of market power-it is simply a division of the payment-for-delivery transaction. Royalties beyond the patent term are no different. If royalties are calculated on post-patent term sales, the calculation is simply a risk-shifting credit arrangement between patentee and licensee. The arrangement can be no more than that, because the patentee at that time has nothing else to sell. $^{88}$

Courts have developed some ways to bypass the Brulotte decision and upheld agreements that differentiate pre- and post-expiration royalty payments, but many industries have still found this alternative to be inadequate. ${ }^{89}$ The per se ban on post-expiration royalties in patent agreements endured, and was reconsidered by the Supreme Court in June $2015 .^{90}$

86. Id. at 1020 ("Thus, as these cases and a tidal wave of legal and economic scholarship point out, the idea that you can use tying to lever your way to a second (or, in the post-expiration patent royalty setting, a longer and therefore greater) monopoly is economic nonsense, imputing systematic irrationality to businessmen.").

87. Id. at 1018 ("However, we have no authority to overrule a Supreme Court decision no matter how dubious its reasoning strikes us, or even how out of touch with the Supreme Court's current thinking the decision seems.").

88. Harold See \& Frank M. Caprio, The Trouble with Brulotte: The Patent Royalty Term and Patent Monopoly Extension, 1990 UTAH L. REV. 813, 814, 851 (1990).

89. Scott W. Doyle et al., Brulotte Rule Upheld Despite Suspect Economic Rationale, LAW360 (June 23, 2015, 6:01 PM), http://www.law360.com/articles/670682/brulotte-rule-upheld-despitesuspect-economic-rationale.

90. See generally Kimble v. Marvel Entm’t, LLC, 135 S. Ct. 2401 (2015). 


\section{Kimble v. Marvel Entertainment, LLC}

In Kimble, the Supreme Court revisited the Brulotte per se ban on postexpiration royalties in patent licensing agreements. ${ }^{91}$ Kimble was an individual inventor who patented a toy that allowed children to pretend they had Spider-Man's powers by shooting string from an apparatus attached to their hand. ${ }^{92}$ He brought this technology to Marvel (maker of many SpiderMan products) hoping to work out a deal for the sale or license of his invention. ${ }^{93}$ Following the meeting, Marvel began marketing a toy dubbed the "Web Blaster," which closely resembled Kimble's patented idea. ${ }^{94}$ A patent infringement suit followed, which resulted in a settlement in the form of a licensing agreement for Kimble's patent that paid a lump sum plus "a $3 \%$ royalty on Marvel's future sales of the Web Blaster and similar products." $" 95$ There was no time limit placed on the payment of royalties in the agreement. ${ }^{96}$

Marvel later learned of the holding in Brulotte, and obtained a declaratory judgment in 2010 that allowed them to cease royalty payments following the expiration of Kimble's patent. ${ }^{97}$ The Ninth Circuit Court of Appeals affirmed the district court ruling, ${ }^{98}$ but not without ample criticism of Brulotte's reasoning: "[T]he Brulotte rule is counterintuitive and its rationale is arguably unconvincing. Nonetheless, recognizing that we are bound by Supreme Court authority and the strong interest in maintaining national uniformity on patent law issues, we have reluctantly applied the rule." $" 99$ The Supreme Court granted certiorari to examine whether Brulotte should be overturned. ${ }^{100}$

\section{a. Industry Involvement}

The grant of certiorari received considerable attention from many intellectual property groups, professional organizations, and other entities with a total of twenty amici curiae briefs subsequently filed: nine supporting

\footnotetext{
91. Id. at 2404.

92. Id. at $2405-06$.

93. Id. at 2406 .

94. Id.

95. Id.

96. Id.

97. Kimble v. Marvel Enters., 692 F. Supp. 2d 1156, 1158, 1161-62 (D. Ariz. 2010).

98. Kimble v. Marvel Enters., 727 F.3d 856, 857 (9th Cir. 2013).

99. Id. at 857 (citations omitted).

100. Marvel Entm't, 135 S. Ct. 2406.
} 
Kimble, ${ }^{101}$ five supporting Marvel, ${ }^{102}$ and six supporting neither party. ${ }^{103} \mathrm{~A}$ variety of parties filed amici briefs, including medical schools, biotechnology companies, medical research centers, and public interest and intellectual property research groups. ${ }^{104}$

Generally, the amici briefs in support of Kimble argued that the Brulotte per se ban (1) increases the cost and complexity of constructing intellectual

101. See generally Brief of BioTime, Inc. as Amicus Curiae in Support of Petitioners, Kimble v. Marvel Entm't, LLC, 135 S. Ct. 2401 (2015) (No. 13-720) [hereinafter BioTime Amicus]; Brief of Amici Curiae Center for Intellectual Property Research of the Indiana University Maurer School of Law \& Other Scholars in Support of Petitioners, Kimble v. Marvel Entm't, LLC, 135 S. Ct. 2401 (2015) (No. 13-720) [hereinafter Indiana University Amicus 1]; Brief of Memorial Sloan-Kettering Cancer Center et al. as Amici Curiae in Support of Petitioners, Kimble v. Marvel Entm't, LLC, 135 S. Ct. 2401 (2015) (No. 13-720), 2015 WL 673668 [hereinafter Memorial Sloan Amicus 1]; Brief of the University of Massachusetts Biologic Laboratories as Amicus Curiae in Support of Petitioners, Kimble v. Marvel Entm't, LLC, 135 S. Ct. 2401 (2015) (No. 13-720) [hereinafter University of Massachusetts Amicus]; Brief for Memorial Sloan Kettering Cancer Center et al. as Amici Curiae in Support of Petitioners, Kimble v. Marvel Entm't, LLC, 135 S. Ct. 2401 (2015) (No. 13-720), 2014 WL 768320 [hereinafter Memorial Sloan Amicus 2]; Brief of the Intellectual Property Law Ass'n of Chicago as Amicus Curiae on Petition for Writ of Certiorari in Support of Petitioners, Kimble v. Marvel Entm't, LLC, 135 S. Ct. 2401 (2015) (No. 13-720) [hereinafter Intellectual Property Law Association Amicus]; Brief of Amici Curiae for the Center for Intellectual Property Research of the Indiana University Maurer School of Law \& Other Legal \& Economic Scholars in Support of Petitioners, Kimble v. Marvel Entm't, LLC, 135 S. Ct. 2401 (2015) (No. 13-720) [hereinafter Indiana University Amicus 2]; Brief of Amicus Curiae New York Intellectual Property Law Ass'n (NYIPLA) in Support of Petitioners, Kimble v. Marvel Entm't, LLC, 135 S. Ct. 2401 (2015) (No. 13-720) [hereinafter New York IP Law Amicus]; Brief of Intellectual Property Owners Ass'n in Support of Petitioners, Kimble v. Marvel Entm't, LLC, 135 S. Ct. 2401 (2015) (No. 13-720) [hereinafter IP Owners Amicus].

102. See generally Brief of Amicus Curiae William Mitchell College of Law Intellectual Property Institute in Support of Respondents, Kimble v. Marvel Entm't, LLC, 135 S. Ct. 2401 (2015) (No. 13-720) [hereinafter William Mitchell Amicus]; Brief of Washington Legal Foundation as Amicus Curiae in Support of Respondent, Kimble v. Marvel Entm't, LLC, 135 S. Ct. 2401 (2015) (No. 13-720) [hereinafter Washington Legal Foundation Amicus]; Brief of Public Knowledge as Amicus Curiae in Support of Respondent, Kimble v. Marvel Entm't, LLC, 135 S. Ct. 2401 (2015) (No. 13-720) [hereinafter Public Knowledge Amicus]; Brief for the United States as Amicus Curiae Supporting Respondent, Kimble v. Marvel Entm't, LLC, 135 S. Ct. 2401 (2015) (No. 13-720) [hereinafter United States Amicus]; Brief of Nautilus, Inc. as Amicus Curiae in Support of Respondent, Kimble v. Marvel Entm't, LLC, 135 S. Ct. 2401 (2015) (No. 13-720) [hereinafter Nautilus Amicus].

103. See generally Brief of Amicus Curiae the Licensing Executives Society (U.S.A. \& Canada), Inc. in Support of Neither Party, Kimble v. Marvel Entm't, LLC, 135 S. Ct. 2401 (2015) (No. 13-720); Brief of the Ass'n of the Bar of the City of New York as Amicus Curiae in Support of Neither Party, Kimble v. Marvel Entm't, LLC, 135 S. Ct. 2401 (2015) (No. 13-720); Brief of the American Intellectual Property Law Ass'n as Amicus Curiae in Support of Neither Party, Kimble v. Marvel Entm't, LLC, 135 S. Ct. 2401 (2015) (No. 13-720); Brief for the United States as Amicus Curiae, Kimble v. Marvel Entm't, LLC, 135 S. Ct. 2401 (2015) (No. 13-720); Brief of the Intellectual Property Law Ass'n of Chicago as Amicus Curiae in Support of Neither Party, Kimble v. Marvel Entm't, LLC, 135 S. Ct. 2401 (2015) (No. 13-720); Brief of Amici Curiae Professor Robin Feldman, Professor Alice Armitage, \& the U.C. Hastings Institute for Innovation Law on Behalf of Neither Party, Kimble v. Marvel Entm't, LLC, 135 S. Ct. 2401 (2015) (No. 13-720).

104. See supra notes 101-103. 
property license agreements, ${ }^{105}$ (2) is not in line with current Court rulings and decisions, ${ }^{106}$ (3) ignores the economic benefits of post-expiration royalties, ${ }^{107}$ (4) damages public welfare in regard to scientific medical research, ${ }^{108}$ and (5) exposes unsophisticated or unknowledgeable parties to unjust results. ${ }^{109}$ The amici briefs argued that a rule-of-reason approach should replace the per se ban. ${ }^{110}$ Rule of reason is the default approach used by the courts for cases resulting from antitrust allegations. ${ }^{11}$ The rule-ofreason approach directs the trier of fact to "decide whether the questioned practice imposes an unreasonable restraint on competition, taking into account a variety of factors, including specific information about the relevant business, its condition before and after the restraint was imposed, and the restraint's history, nature, and effect." 112

Conversely, the amici briefs supporting Marvel argued (1) the Courts have continuously upheld Brulotte, ${ }^{113}$ (2) a rule-of-reason approach would not prevent patent abuse and is inappropriate in these cases, ${ }^{114}$ (3) the doctrine of stare decisis discourages overturning decisions based on the construction of federal statutes, ${ }^{115}$ and (4) Brulotte does not obstruct contract negotiations or have any negative impact on the economy. ${ }^{116}$ The three remaining neutral amici briefs argued both sides' points. ${ }^{117}$

\section{b. The Supreme Court Upholds Brulotte}

Before the Court, Kimble first argued that the Brulotte per se ban on post-expiration royalties should be discarded and replaced by a rule-ofreason approach. ${ }^{118}$ A rule of reason would have the Court utilize a "flexible, case-by-case analysis" when evaluating patent licensing 25.

105. BioTime Amicus, supra note 101, at 3-9; Memorial Sloan Amicus 1, supra note 101, at 23-

106. Indiana University Amicus 1, supra note 101, at 12-20; Memorial Sloan Amicus 1, supra note 101, at 19-23; University of Massachusetts Amicus, supra note 101, at 27-35.

107. Memorial Sloan Amicus 1, supra note 101, at 17-18, 21-24.

108. Id. at 9-15.

109. University of Massachusetts Amicus, supra note 101, at 33-35.

110. BioTime Amicus, supra note 101, at 2-3; Memorial Sloan Amicus 1, supra note 101 at 1923; University of Massachusetts Amicus, supra note 101, at 22.

111. State Oil Co. v. Khan, 522 U.S. 3, 10 (1997).

112. Id. (citing Arizona v. Maricopa Cty. Med. Soc'y, 457 U.S. 332, 343 (1982)).

113. William Mitchell Amicus, supra note 102, at 9-14; Washington Legal Foundation Amicus, supra note 102, at 9-13.

114. Public Knowledge Amicus, supra note 102, at 2-22.

115. Washington Legal Foundation Amicus, supra note 102, at 9-17.

116. Id. at $17-21$.

117. See generally supra note 103.

118. Kimble v. Marvel Entm't, LLC, 135 S. Ct. 2401, 2408 (2015). 
agreements similar to the approach in antitrust law. ${ }^{119}$ Specifically, Kimble highlighted the need for the Court to examine (through a variety of factors) whether the patentee truly had the power and ability to actually extend their patent rights in the marketplace and "curtail competition." 120

Kimble next argued that the Brulotte rule was based on the faulty economic theory that license agreements including post-expiration royalties "are invariably anticompetitive."121 He pointed out that longer payback periods usually result in lower royalty rates, which in turn lowers retail prices. ${ }^{122}$ Lower rates paid back to the patentee, Kimble argued, "enable more companies to afford a license, fostering competition among the patent's own users." "123 Further, Kimble noted that, unless there was a barrier for other companies to enter the market, the post-expiration royalty structure actually "encourages new companies to begin making the product" by offering a lower price to attract consumers. ${ }^{124}$

The Court did not delve into the economic argument put forth by Kimble because it said Brulotte was not an antitrust case:

We do not join issue with Kimble's economics - only with what follows from it. A broad scholarly consensus supports Kimble's view of the competitive effects of post-expiration royalties, and we see no error in that shared analysis. ...

If Brulotte were an antitrust rather than a patent case, we might answer both questions as Kimble would like. ...

... Brulotte did not hinge on the mistake Kimble identifies.... [I]n deciding whether post-expiration royalties comport with patent law, Brulotte did not undertake to assess that practice's likely competitive effects. Instead, it applied a categorical principle that all patents, and all benefits from them, must end when their terms expire.

Finally, Kimble argued that a per se ban on post-expiration royalties have a harmful effect on innovation and the economy as a whole. ${ }^{126} \mathrm{He}$ posited that the per se ban would prevent parties from entering into ideal

119. Id. (quoting Brief for Petitioners at 45, Kimble v. Marvel Entm't, LLC, 135 S. Ct. 2401 (2015) (No. 13-720)).

120. Id. at 2408-09.

121. Id. at 2412 (quoting Brief for Petitioners at 37, Kimble v. Marvel Entm't, LLC, 135 S. Ct. 2401 (2015) (No. 13-720)).

122. Id.

123. Id.

124. Id.

125. Id. at $2412-13$ (citations omitted).

126. Id. at 2414 . 
long-term contracts that mitigate risk. ${ }^{127}$ Preventing such contracts could prevent parties from reaching any sort of agreement and bar innovative technologies from the market altogether. ${ }^{128}$ The Court was not convinced, and cited the lack of empirical evidence supporting Kimble's argument. ${ }^{129}$

Ultimately, the Court, in a six-to-three decision written by Justice Kagan, found the doctrine of stare decisis was too great to overturn and replace the Brulotte decision with the rule of reason. ${ }^{130}$ The Court found that precedent carries extra weight when the Court performs statutory construction, which is what the Court did in Brulotte. ${ }^{131}$ Justice Kagan noted that Congress had the ability to make changes to relevant statutes once the Court interprets them, and in this case Congress had not replaced the Brulotte per se ban despite "repeatedly amend[ing] the patent laws" since that decision. ${ }^{132}$ Further, the Court believed the rule-of-reason alternative would provide a less-workable alternative to the per se ban, and as such "the case for sticking with long-settled precedent [grew] stronger." 133 The Court did acknowledge the merits of Kimble's economic arguments, and noted the strength of the support of the various amici briefs: "A broad scholarly consensus supports Kimble's view of the competitive effects of postexpiration royalties, and we see no error in that shared analysis." 134

However, the Court found that this was not an antitrust case, but one based on a statutory construction of patent law. ${ }^{135}$ Since the Court viewed Brulotte as an exercise in statutory interpretation, the Court did not explore the substantive economic arguments. ${ }^{136}$ As a result, even while recognizing the validity of Kimble's complaints, the Court affirmed the Brulotte per se ban on post-expiration royalties, and instructed opponents of the per se ban to seek the desired changes from Congress. ${ }^{137}$

\footnotetext{
127. Id.

128. Id.

129. Id. ("Neither Kimble nor his amici have offered any empirical evidence connecting Brulotte to decreased innovation; they essentially ask us to take their word for the problem.").

130. Id. at 2409-12 ("[A]n argument that we got something wrong - even a good argument to that effect — cannot by itself justify scrapping settled precedent.").

131. Id. at 2409 .

132. Id. at 2410 .

133. Id. at 2411 .

134. Id. at 2412 .

135. Id. at 2413 .

136. Id. at 2414 (quoting Halliburton Co. v. Erica P. John Fund, Inc., 134 S. Ct. 2398, 2413 (2014)) ("Truth be told, if forced to decide [whether Brulotte has caused economic harm], we would not know where or how to start. Which is one good reason why that is not our job. Claims that a statutory precedent has 'serious and harmful consequences' for innovation are (to repeat this opinion's refrain) 'more appropriately addressed to Congress."').

137. Id. (citations omitted) ("Congress legislates actively with respect to patents, considering concerns of just the kind Kimble raises. In adhering to our precedent as against such complaints, we
} 


\section{c. A Super-Powered Dissent}

Justice Alito delivered a dissent in Kimble that attacked the majority for "employ[ing] stare decisis, normally a tool of restraint, to reaffirm a clear case of judicial overreach." 138 He wrote that Brulotte was in no way a construction of patent laws, and was clearly based on bad economic theory. ${ }^{139}$ In support of this point, Justice Alito noted that there is absolutely nothing in the Patent Act that prevents post-expiration royalties, and that the majority did not even try to show that Brulotte utilized statutory construction. ${ }^{140}$ As a result, Justice Alito viewed Brulotte as "a bald act of policymaking." $" 141$

Next, the dissent critiqued the antitrust concerns expressed by Brulotte and affirmed by the majority. ${ }^{142}$ Citing scholarly articles and other Supreme Court decisions, Justice Alito wrote that post-expiration royalties do not extend a patent monopoly ${ }^{143}$ and can actually have positive "pro-competitive effects." "144 In fact, the dissent explained that positive and efficient economic results can come from "spreading licensing fees over longer periods" and that Brulotte's per se ban on these licensing agreements results in economic inefficiency. ${ }^{145}$

The majority explained that there are workarounds to the Brulotte per se ban "enabling [parties] to achieve those same ends," 146 but the dissent aptly responded by arguing, "the need to avoid Brulotte is an economic inefficiency in itself." 147 To further his point, Justice Alito cited Supreme Court decisions that "abandoned per se rules [in patent law and other areas]

promote the rule-of-law values to which courts must attend while leaving matters of public policy to Congress.").

138. Id. at 2415 (Alito, J., dissenting).

139. Id. ("That decision was not based on anything that can plausibly be regarded as an interpretation of the terms of the Patent Act. It was based instead on an economic theory-and one that has been debunked.").

140. Id.

141. Id. ("[Brulotte] was not simply a case of incorrect statutory interpretation. It was not really statutory interpretation at all.").

142. Id. at $2415-16$.

143. Id. at 2416 (quoting Frank H. Easterbrook, Contract and Copyright, 42 Hous. L. Rev. 953, 955 (2005)) (“Instead, '[o]nce the patent term expires, the power to exclude is gone,' and all that is left 'is a problem about optimal contract design."').

144. Id. at 2415-16 ("Not only was Brulotte based on policymaking, it was based on a policy that is difficult to defend. Indeed, in the intervening 50 years, its reasoning has been soundly refuted.").

145. Id. at 2416 .

146. Id. at 2408 (majority opinion).

147. Id. at 2416 (Alito, J., dissenting). 
with similarly disruptive effects." ${ }^{, 148}$

The dissent also wrote that the Brulotte rule frustrated contractual expectations of the two parties to the licensing agreement. ${ }^{149}$ Both parties agreed on the royalty structure in the agreement, and intended for the payments to continue for as long as Marvel sold their Web Blaster toy based on Kimble's invention. ${ }^{150}$ The majority argued, "[s]o long as we see a reasonable possibility that parties have structured their business transactions in light of Brulotte, we have one more reason to let it stand." "Justice Alito responded by stating, "there is no real uncertainty" as to whether or not Marvel intended Brulotte to be the default rule when it contracted with Kimble, and, alternatively, "[w] hat we know for sure ... is that Brulotte has upended the parties' expectations here and in many other cases." 152

The majority's prescribed solution for critics of their decision was to turn to Congress for a law allowing post-expiration royalties. ${ }^{153}$ However, the dissent warned "[p]assing legislation is no easy task." ${ }^{\text {Utimately, }}$ Justice Alito wrote that upholding Brulotte's per se ban on post-expiration royalties was based on nothing more than inappropriately adhering to the doctrine of stare decisis:

In the end, Brulotte's only virtue is that we decided it. But that does not render it invincible....

Our traditional approach to stare decisis does not require us to retain Brulotte's per se rule. Brulotte's holding had no basis in the law. Its reasoning has been thoroughly disproved. It poses economic barriers that stifle innovation. And it unsettles contractual expectations.

148. Id. at 2415 (citing Illinois Tool Works Inc. v. Indep. Ink, Inc., 547 U.S. 28 (2006); Leegin Creative Leather Prods., Inc. v. PSKS, Inc., 551 U.S. 877 (2007)).

149. Id. at 2417 ("[B]oth sides expected the royalty payments to continue until Marvel stopped selling toys that fit the terms of the agreement. But that is not what happened. When Marvel discovered Brulotte, it used that decision to nullify a key part of the agreement. The parties' contractual expectations were shattered, and petitioners' rights were extinguished.").

150. Id.

151. Id. at 2410 (majority opinion).

152. Id. at 2417 (Alito, J., dissenting) (citations omitted).

153. Id. at $2414-15$ (majority opinion).

154. Id. at 2418-19 (Alito, J., dissenting) (citations omitted) ("A federal statute must withstand the 'finely wrought' procedure of bicameralism and presentment. Within that onerous process, there are additional practical hurdles. A law must be taken up for discussion and not passed over in favor of more pressing matters, and Senate rules require 60 votes to end debate on most legislation. And even if the House and Senate agree on a general policy, the details of the measure usually must be hammered out in a conference committee and repassed by both Houses."); see also SCHOOLHOUSE RocK, I'm Just a Bill, YouTUBE (Sept. 1, 2008), https://www.youtube.com/watch?v=tyeJ55o3El0. 
Even taking the Court on its own terms, Brulotte was an antitrust decision masquerading as a patent case. ${ }^{155}$

The majority improperly adhered to the doctrine of stare decisis, which reinforced a rule that results in economic inefficiency, decreases innovation, and frustrates the contractual intentions of parties. Parties must now either expend considerable resources contracting around the per se ban, or pursue legislative action in Congress.

\section{ANALYSIS}

The per se ban on post-expiration royalties in patent licensing agreements is a rigid rule that cuts against the main goals of the patent system by promoting economic inefficiency and diminishing innovation. Because of this ruling, parties must work around the rule when they contract to protect their future economic interests. This economic inefficient strategy should not endure. A federal statute utilizing a rule-of-reason approach should govern patent licensing agreements with post-expiration royalties. The rule-of-reason approach would empower courts to factually investigate a patent licensing agreement for anti-competitive effects and extension of the patent monopoly beyond the expiration date.

\section{A. Critique of the Supreme Court's Rationale}

The Supreme Court refused to delve into the economic and policy arguments offered by Kimble because they incorrectly interpreted Brulotte as an exercise in statutory construction. Had the Court recognized the complete absence of canons of statutory construction and ubiquitous antitrust considerations, they would have been able to fully consider Kimble's economic arguments. Recognizing Brulotte as an antitrust case would have enabled the Court to use the rule-of-reason approach in evaluating Kimble's arguments, and would have likely overturned Brulotte's per se ban on post-expiration patent royalties.

1. Brulotte Did Not Utilize Any Canons of Statutory Construction and Explicitly Cited Antitrust Concerns as the Basis for the Per Se Ban.

The Supreme Court upheld Brulotte because stare decisis is a stronger force when the Court interprets a statute. ${ }^{156}$ In fact, the majority admitted

155. Kimble, 135 S. Ct. at 2417-18 (2015) (Alito, J., dissenting) (citations omitted).

156. Id. at 2409-10, 2415 (majority opinion). 
that if Brulotte was truly an antitrust case they could very well have decided Kimble in the alternative. ${ }^{157}$ However, when one examines the holding in Brulotte, it is clear that antitrust considerations were the root of the decision. ${ }^{158}$

The Court in Brulotte believed that patent licensing agreements including post-expiration royalties were an attempt by the patentee to continue extracting benefits from the patents after the monopoly power had expired. ${ }^{159}$ In addition, by adopting the per se ban against such royalty arrangements, the Brulotte Court believed it was offering protection to the free market from undue monopolistic influence. ${ }^{160}$ Finally, the Brulotte Court recognized the right of patent owners to leverage their monopoly power during the patent term, but that post-expiration royalties were akin to extending that power indefinitely. ${ }^{161}$ Clearly, the Brulotte Court was deeply concerned that patent holders could extend their monopoly right in perpetuity.

Nowhere in the Brulotte decision did the Court discuss construction of statutory provisions. ${ }^{162}$ A typical exercise of statutory construction would utilize traditional canons and methods to determine the intent behind the law and resolve ambiguities in the text. ${ }^{163}$ A court's approach to statutory construction can vary depending on what controlling theory the court utilizes ("textualism, intentionalism, [or] pragmatism"), which will alter how the court analyzes the legislative intent behind the statute in question. ${ }^{164}$ The Brulotte Court made no mention of a particular theory through which they analyzed a statute, nor utilized any sort of textual analysis or discussion. ${ }^{165}$ The only mention of statutory provisions was a brief quotation of: (1) a

157. Id. at 2412 ("If Brulotte were an antitrust rather than a patent case, we might answer both questions as Kimble would like.").

158. Brulotte v. Thys Co., 379 U.S. 29, 32-33 (1964).

159. Id. at 32 ("The contracts [for post-expiration royalties] are, therefore, on their face a bald attempt to exact the same terms and conditions for the period after the patents have expired as they do for the monopoly period.").

160. Id. at 32-33 ("In light of those considerations, we conclude that a patentee's use of a royalty agreement that projects beyond the expiration date of the patent is unlawful per se. If that device were available to patentees, the free market visualized for the post-expiration period would be subject to monopoly influences that have no proper place there.").

161. Id. at 33 ("A patent empowers the owner to exact royalties as high as he can negotiate with the leverage of that monopoly. But to use that leverage to project those royalty payments beyond the life of the patent is analogous to an effort to enlarge the monopoly of the patent ....").

162. See generally id. at 29-34.

163. Jacob Scott, Codified Canons and the Common Law of Interpretation, 98 GEO. L.J. 341, 343 (2010) ("Statutory construction has a vocabulary consisting of rules of thumb that are said to allow readers to draw inferences about the meaning of a particular statute.").

164. Id.

165. See generally Brulotte, 379 U.S. at 29-34. 
portion of Article $1, \S 8$ of the Constitution, which authorizes Congress the right to grant inventors temporary monopoly rights for their inventions; and (2) a single sentence from 15 U.S.C. $\S 154$ highlighting the temporary monopoly term granted to inventors. ${ }^{166}$ The Brulotte opinion's clear text shows that the per se ban was based on the fear of extending the patent monopoly beyond the expiration date, and not on statutory construction. In fact, as the dissent in Kimble argued, there is no statutory provision that "forbids licensing agreements that provide for post-expiration royalties."

\section{If the Kimble Court Correctly Reviewed Brulotte as an Antitrust}

Case, They Would Have Found That Post-Expiration Royalties Do

Not Impermissibly Extend the Patent Monopoly.

The majority in Kimble should have viewed the decision in Brulotte as one steeped in antitrust concerns, and evaluated those concerns based on established economic principles. Patent rights give the inventor "the right to exclude others from making, using, offering for sale, or selling the invention," ${ }^{168}$ but only for a statutorily proscribed period. ${ }^{169}$ The right of exclusion is the monopoly power wielded by the patent owner, and once the patent expires he or she holds no legal power to prevent others from using or producing the invention. Once Kimble's patent expired, the only legal right he possessed was the contractual agreement with Marvel to receive 3\% royalties for as long as Marvel continued to make its product.

Hypothetically, if toy manufacturer $\mathrm{X}$ began making a similar Web Blaster toy, neither Kimble nor Marvel would have the right to pursue legal recourse against $\mathrm{X}$. The patent would have expired, and there would be no exclusionary (monopoly) power possessed by Kimble or Marvel to prevent $\mathrm{X}$ from making and selling a Web Blaster. The main change for Kimble would be the amount of payment he would receive from Marvel. Because Marvel would not be the exclusive purveyor of the Web Blaster, their market share would decrease. Kimble would still receive $3 \%$ royalty payments, but more competition in the market would gradually decrease the payment amounts. The dissent generally discussed this concept in Kimble, ${ }^{170}$ and has

166. See id. at 30 (citing U.S. CONST. art. 1, § 8, cl. 8, which states Congress has the power "[t]o promote the Progress of Science and useful Arts, by securing for limited Times to Authors and Inventors the exclusive Right to their respective Writings and Discoveries").

167. Kimble v. Marvel Entm't, LLC, 135 S. Ct. 2401, 2415 (2015) (Alito, J., dissenting).

168. 35 U.S.C. $§ 154(a)(1)$ (Supp. 2014).

169. 35 U.S.C. $\S 154(a)(2)$ (Supp. 2014).

170. Kimble, 135 S. Ct. at 2416 (Alito, J., dissenting) (citations omitted) ("As the Court understood such an arrangement, the patent holder leverages its monopoly power during the patent term to require payments after the term ends, when the invention would otherwise be available for 
been discussed by courts in other patent licensing decisions as a reason for doubting Brulotte's antitrust concerns. ${ }^{171}$ Scholarly articles have also criticized Brulotte's holding to this effect. ${ }^{172}$

The Brulotte per se ban on post-expiration royalties in patent licensing agreements is based on an unfounded fear of monopoly extension. If the majority in Kimble had analyzed this as an antitrust issue (as the Court in Brulotte did) they surely would have overturned the per se ban. Instead, the Court incorrectly viewed Brulotte as an exercise in statutory construction, and as a result, royalties in patent licensing agreements are affected by an economically debunked justification.

3. Since Brulotte Was an Antitrust Case, Not Statutory Interpretation, the Kimble Court Should Have Employed the Rule-of-Reason

Approach.

Since Brulotte was a decision based on antitrust concerns, the per se ban should have been abandoned for the rule-of-reason approach, the default standard employed by courts when dealing with antitrust allegations. ${ }^{173}$ Here the rule-of-reason approach would have empowered the Court to investigate the royalty agreement between Kimble and Marvel and its effect on the superhero toy industry. As discussed in Part III(A)(2), because Kimble and Marvel no longer held any legal patent rights post-expiration, it is unlikely the Court would find that Kimble continued to exert his exclusionary right on the market. Of course, the Court could still have found the arrangement to be problematic. However, this would have been a result of a detailed, factual, and specific inquiry into the relevant market, not on a blind per se prohibition.

\section{B. Implications of Upholding the Per Se Ban}

Affirming the per se ban on post expiration royalties preserved a burdensome rule, which will lead to many undesirable policy consequences. Patent licensing agreements vary in scope and complexity across a myriad of industries. Preventing companies and inventors from entering into patent licensing agreements that include post-expiration royalties will create an industry of economic inefficiency and unnecessary contractual complexity.

\footnotetext{
free public use. But agreements to pay licensing fees after a patent expires do not "enlarge the monopoly of the patent."').

171. See, e.g., Scheiber v. Dolby Labs., Inc., 293 F.3d 1014, 1017-18 (7th Cir. 2002).

172. See \& Caprio, supra note 88 , at $838-54$, and accompanying text.

173. State Oil Co. v. Khan, 522 U.S. 3, 10 (1997).
} 
Less efficient operations and higher contracting cost will damage progress and innovation and can lead to unjust results for unsophisticated parties.

1. The Brulotte Per Se Ban on Post-Expiration Patent Royalties Is a Rigid Rule Governing Complex Agreements, and Does Not Take into Account All of the Circumstances Surrounding the Transaction.

The Supreme Court has addressed similar per se doctrines in the past and subsequently has replaced them with more holistic analysis standards. ${ }^{174}$ In Illinois Tool Works, Inc., the Court reviewed a per se ban on tying arrangements ${ }^{175}$ in patent licensing agreements. ${ }^{176}$ The justification for the per se ban was similar to the one espoused by the Brulotte Court- that such an arrangement gave the patent holder greater market power which was a per se violation of antitrust laws. ${ }^{177}$ The presumptions for these agreements assumed that "by tying the purchase of unpatented goods to the sale of the patented good, the patentee was "restraining competition.",178 The Court pushed back against this presumption, and concluded that "while some such arrangements are still unlawful" the conclusion that the patent holder exerts impermissible monopoly power on the market "must be supported by proof of power in the relevant market rather than by a mere presumption thereof." 179

Discarding the per se ban in Illinois Tool Works did not legalize tying arrangements. Instead, the Court ensured that complex business agreements received a fair amount of scrutiny to decide whether impermissible monopoly power was truly exerted on the market. By allowing such agreements, the Court empowered individuals and businesses to contract freely without a per se obstacle blocking an otherwise economically efficient arrangement.

By upholding the Brulotte per se ban on post-expiration royalties, the Kimble Court left in place a barrier to possible economic efficiency. In some instances, extending patent royalties is the only thing that is economically possible. Memorial Sloan-Kettering Cancer Center, in conjunction with other medical research centers, filed an amicus brief in

174. See generally Ill. Tool Works Inc. v. Indep. Ink, Inc., 547 U.S. 28 (2006); Leegin Creative Leather Prods., Inc. v. PSKS, Inc., 551 U.S. 877 (2007).

175. See supra note 72 .

176. Ill. Tool Works, Inc., 547 U.S. at 31.

177. Id. at $37-38$.

178. Id. at 38 (quoting Morton Salt Co. v. G.S. Suppiger Co., 314 U.S. 488, 490 (1942)).

179. Id. at 42-43. The Court noted that relevant evidence to prove the presumption included a definition of the market in which the patent holder operates, and proof that the patent actually confers him or her greater power within the defined market. Id. at 45-46. 
support of Kimble that argued this point. ${ }^{180}$ Medical research facilities conduct extensive research for new pharmaceutical drugs and treatments to various medical conditions. ${ }^{181}$ Often, these new drugs and treatments take a large amount of time and expense in the development stages. ${ }^{182}$ For both large and small companies alike, it makes economic sense to defer royalty payments during the development and testing stages for royalties after the drug goes to market —oftentimes after the patent term has expired. ${ }^{183}$

If the Court utilized an analysis standard like the one seen in Illinois Tool Works, these agreements could be critically examined to determine if the post-expiration royalty structure was extending the patent monopoly of the medical research center beyond the patent term. The Court would still be able to strike down the agreement if they found the agreement to evoke antitrust concerns. However, by upholding the Brulotte per se ban, the Kimble Court placed a barrier in front of companies preventing them from constructing efficient patent licensing agreements.

\section{The Per Se Ban Subjects Unsophisticated Parties to Unjust Results, and Frustrates Original Contractual Expectations.}

The rigidity of the per se ban on post-expiration royalties exposes unsophisticated parties to unjust results simply because they are unaware of Brulotte. In the case at issue, Kimble was an individual inventor entering into a licensing agreement with a major corporation. ${ }^{184}$ Both parties negotiated the royalty structure as a result of a settlement in a patent infringement case brought by Kimble against Marvel. ${ }^{185}$ It was not until later that Marvel claimed to have "stumbled across Brulotte."186 The majority in Kimble commented that "Marvel must have been pleased to learn of it." ${ }^{\text {"87 }}$ By affirming Brulotte, the Kimble Court opened the door for companies to "stumble across" Brulotte and use it as a reason for invalidating a negotiated, bargained-for agreement.

A party as an individual inventor may not have the legal acumen or available funds to become legally sophisticated in the area of patent licensing agreements. Coming to the table with a business (large or small)

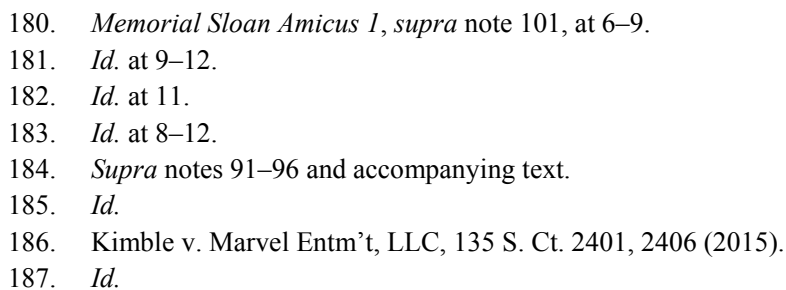


puts them at a disadvantage when negotiating their royalty structures. If a company proposes a royalty structure that starts with small percentage payments and increases over time beyond the patent term when the product becomes more commercially viable, the individual may see that as an attractive offer since he or she will receive payments for as long as the company sells his or her product. Now that Brulotte's per se ban on postexpiration royalties has been upheld, all that it takes for the company to withhold its payments is to "stumble across" Brulotte. Meanwhile, the unsophisticated party is left with a fraction of what his patented product is worth in the market. Brulotte's per se ban frustrates an unsophisticated party's contractual expectations, and makes "stumbling across" Brulotte a good business strategy for sophisticated companies.

\section{The Per Se Ban on Post-Expiration Royalties Thwarts the Purpose of the United States Patent System.}

One of the major goals of the patent system is to incentivize innovation by allowing inventors to (temporarily) reap the benefits of their labor. ${ }^{188}$ As discussed in Part III(B)(2), the Brulotte per se ban injects added complexity into already complicated agreements - particularly in the medical research and biotechnology fields. In these fields, immense amount of time and money are needed to develop new drugs and technology. Considering the considerable time and expense necessary to contract around Brulotte's per se ban, ${ }^{189}$ individuals may leave the industry all together upon discovering that they can not get adequate returns on their investment through licensing agreements. The goal of the patent system is to spur innovation, and if individuals leave an industry because they cannot be economically viable due to Brulotte's per se ban, then the Court has thwarted the goals of the patent system.

A company's economic interest is not the only thing damaged by Brulotte's per se ban. For example, smaller research companies may have to devote a majority of their funds to the development of a new drug or treatment. ${ }^{190}$ The choice of whether to pursue such research will hinge largely on the ability to commercialize their research in the future. If the new drug or treatment will not be economically viable until after the patent has expired, the company will head in a new, more profitable direction, or leave the industry all together. While the economic interests of the company

188. Merges ET AL., supra note 17, at 125.

189. See infra Section III(B)(4).

190. Memorial Sloan Amicus 1, supra note 101, at 11. 
are surely damaged, the public at large will be deprived of new innovative medical technology. In a market-driven society, the eventual commercialization of research and development is what incentivizes large up-front investment. If a per se ban on post-expiration royalties makes it unlikely that a company will reap financial gain, the public loses access to innovative medical advances and technology.

\section{A Per Se Ban on Post-Expiration Royalties Does Not Effectively Bar Such Agreements.}

The majority in Kimble went as far as to outline how "parties can often find ways around Brulotte, enabling them to achieve those same ends." For instance, a licensing agreement can provide for post-expiration royalty payments, so long as they are payments resulting from profits acquired prior to the expiration of the patent. ${ }^{192}$ This practice, however, merely amortizes royalty payments during the patent term over a period extending beyond the patent's expiration. It still does not permit the patentee to collect royalty payments from the licensor based on post-expiration use of the licensed patent. Therefore, it really is not a workaround to the per se ban at all. Furthermore, in a licensing agreement comprised of multiple patents, parties can contract for royalty payments until all of the patents have expired. ${ }^{193}$ Finally, parties can continue royalty payments post-expiration as long as the royalty rate is attached to a "non-patent right." 194

While these options are available, requiring parties to investigate and utilize such workarounds is costly, and results in economic waste. Furthermore, if a company is not as sophisticated in their contract drafting capabilities (e.g. a small start-up versus a global corporation), the complexity of properly drafting around Brulotte may result in voided licensing agreements and increasing amounts of litigation. The fields of medical research and biotechnology are exponentially more complicated relative to the agreement between Kimble and Marvel (a license for a single utility patent).

BioTime, Inc., a biotechnology company, argued these points in their amicus brief based on their significant experience with patent licensing

\footnotetext{
191. Kimble, 135 S. Ct. at 2408.

192. Id. See also Brulotte v. Thys. Co., 369 U.S. 29, 31 (1964).

193. Kimble, 135 S. Ct. at 2408. See also Brulotte, 369 U.S. at 30.

194. Kimble, 135 S. Ct. at 2408. See also Milgrim \& BENSON, supra note 36, at $\S 18.07$ ("[G]iven the limit on the permissible duration of patent royalty to the life of the patent, and the potentially unlimited duration of a trade secret royalty, which is determined solely by the parties' contract, a licensor of both patents and trade secrets may allocate royalty and perhaps secure long term advantages.").
} 
transactions. ${ }^{195}$ In their field of scientific research, regenerative medicine, the scope of patent licensing agreements often encompasses a high number of patents and patent applications simultaneously. ${ }^{196}$ At the outset of the agreement, the future scope of these patents and patent applications may not be entirely known. ${ }^{197}$ Intellectual property licensing agreements such as these are inherently difficult to define because they do not involve easily discernable rights and products as seen in licensing agreements for real property. ${ }^{198}$ Because of this uncertainty, these agreements may opt for lower royalty payments at the outset in lieu of royalty payments after the product is actually commercially viable. ${ }^{199}$ By upholding the Brulotte rule, the Kimble Court injects even more complexity into an already convoluted transaction.

Research companies such as BioTime, Inc., must now attempt to utilize one of the workarounds to the Brulotte per se ban on post-expiration royalties while at the same time dealing with the uncertainty of the scope of their intellectual property in the future. Because of these uncertain agreements, a company may end up doing all of the upfront research, investment, and labor, and reap none of the commercial rewards.

\section{A Federal Statute Governing Post-Expiration Royalties}

The per se ban on post-expiration royalties in patent agreements is a rigid bar to efficient economic contracting, and will have negative policy implications. The contractual workarounds outlined by the majority in Kimble are insufficient since they require increased legal sophistication and economic investment from contracting parties. While the Supreme Court in Kimble incorrectly found Brulotte to be an exercise of statutory interpretation, the antitrust sentiments espoused by the Brulotte Court are valid concerns. Monopolistic actions and restraint of trade go against the ideals of the free market and should be policed. However, a patent licensing agreement including post-expiration royalties does not per se result in extension of the patent monopoly beyond its expiration date. In response, a new federal statute should be enacted that enables parties to freely contract for use and profit of a patented invention, while empowering the courts to review patent licensing agreements in light of relevant antitrust concerns.

\footnotetext{
195. See generally BioTime Amicus, supra note 101, at 1-9.

196. Id. at $1-3$.

197. Id.

198. Richard A. Posner, Transaction Costs and Antitrust Concerns in the Licensing of Intellectual Property, 4 J. MARSHALL ReV. INTELL. PROP. L. 325, 325 (2005).

199. Alfred C. Server et al., Reach-Through Rights and the Patentability, Enforcement, and Licensing of Patents on Drug Discovery Tools, 1 HASTINGS SCI. \& TECH. L.J. 21, 62 (2008).
} 
1. Patent Licensing Agreements Including Post-Expiration Royalties

Should Be in the Purview of the Sherman Act.

A patent by definition is a limited monopoly, granting the user the power to exclude all others from using, making, or selling the patented invention. ${ }^{200}$ Antitrust concerns arise when the owner of the patent attempts to extend the limited monopoly beyond the expiration date in perpetuity. This was the true concern of the Brulotte Court when faced with a patent licensing agreement that included post-expiration royalties. ${ }^{201}$ However, just because the licensing agreement could result in monopolization or restraint of trade does not mean such agreements should be illegal per se-especially when the courts have an existing statutory framework under which patent licensing agreements with post-expiration royalties could be evaluated.

The Sherman Act was passed in the United States in 1890, and it reflected the anti-monopoly concerns originally combatted by the Statute of Monopolies. ${ }^{202}$ The implementation and enforcement of the Sherman Act largely resides in the judiciary due to its relative brevity as compared to other statutes. ${ }^{203}$ There is no statutory scheme in United States law that explicitly governs the portion of patent licensing agreements, which include post-expiration royalties. Contract law principles may govern certain aspects of the agreements, but the post-expiration royalties are a question of antitrust law. As a result, Congress should enact a federal statute that scrutinizes such agreements under the provisions of the Sherman Act.

2. The Statutory Language Should Mirror the Brevity of the Sherman

Act, and Direct Courts to Evaluate Patent Licensing Agreements with Post-Expiration Royalties as an Antitrust Case.

The Sherman Act itself does not explicitly define what actions result in monopolization or restraint of trade, but it does explicitly state that these actions are illegal and proscribes penalties for violations. ${ }^{204}$ Mirroring the brief instruction given by Sections 1 and 2 of the Sherman Act, the new federal statute should state that patent licensing transactions including postexpiration royalties may result in violations of Sherman Act Sections 1 and/or 2, and direct courts to utilize an antitrust analysis to examine the agreement. For example:

200. See supra note 6 and accompanying text.

201. See supra notes 69-75 and accompanying text.

202. See supra notes 55-61 and accompanying text.

203. See supra notes 55-61 and accompanying text.

204. See supra notes 58-61. 
Patent license agreements providing for post-expiration royalties are illegal if the royalty structure violates Sections 1 and/or 2 of the Sherman Act. If such agreement is found to result in monopolization or restraint of trade, all relevant penalties under Sections 1 and 2 of the Sherman Act shall apply .... .

Enacting this new statute will allow parties to enter into patent licensing agreements without investing significant time and money into drafting around a per se ban on post-expiration royalties.

Absent the per se ban, new technologies will have less barriers to market participation. By deferring royalty payments, inventors who develop innovative technological advances will still enjoy the fruits of their labor even if the innovation is not marketable until long after the patent's expiration date. A new federal statute abolishing the per se ban on postexpiration royalties will have a positive effect on innovation and reduce economic waste while empowering the court to police such agreements for monopolistic effects on the market. There is a well-established body of antitrust law created by the judiciary that courts can rely upon to accurately and efficiently examine patent licensing agreements with post-expiration royalties for antitrust violations. ${ }^{205}$

\section{Using the Rule-of-Reason Approach, Courts Will Be Able to}

Determine if a Patent Licensing Agreement Including Post-

Expiration Royalties Actually Violates the Sherman Act.

Once the new federal statute incorporates these patent licensing agreements into the Sherman Act's framework, the courts will evaluate the agreements utilizing the rule of reason, the default standard for antitrust cases. $^{206}$ Because antitrust cases necessitate a robust factual inquiry, ${ }^{207}$ parties will have the opportunity to offer evidence to show that no monopolistic activity or restraint of trade occurred because of their agreement. Courts will be able to evaluate the agreement in light of relevant factors including, but not limited to, the parties' conduct, the market in question, each party's role in the market, and the effect (if any) the licensing agreement has on competition within the market. ${ }^{208}$

The rule of reason is a malleable analysis standard that will provide courts the flexible framework necessary to evaluate patent licensing

\footnotetext{
205. Supra Section III(A)(3) for a discussion regarding the rule-of-reason approach.

206. Supra Section III(A)(3) for a discussion regarding the rule-of-reason approach.

207. Supra Section III(A)(3) for a discussion regarding the rule-of-reason approach.

208. Supra notes 118-20 and accompanying text.
} 
agreements from a myriad of different industries. The patent licensing agreement in Kimble included a single utility patent, and thus would be a relatively simple analysis for the court. In addition, the rule of reason would provide the courts with the tools necessary to evaluate complex licensing agreements from the biotech or medical research industries. A federal statute abolishing the per se ban on post-expiration royalties in patent licensing agreements will have a positive effect on innovation and the economy and will direct the courts to utilize a well-developed antitrust evaluation system to analyze such agreements for violations of the Sherman Act.

\section{CONCLUSION}

The Brulotte per se ban on post-expiration patent royalties endures today because the Kimble Court incorrectly viewed the Brulotte decision as an exercise in statutory construction. The Kimble Court should have instead viewed Brulotte as an antitrust decision that necessitated the use of the ruleof-reason approach. Enacting a new federal statute that places patent licensing agreements with post-expiration royalties within the purview of the Sherman Act instead will allow parties to freely contract with one another without having to employ economically inefficient alternatives. Each challenged agreement would be evaluated based on all of the factual circumstances and an analysis of the relevant market to be sure that antitrust laws were not violated. Instead, the per se ban remains, and parties must endure a rigid per se barrier that results in economic inefficiency, stifling of innovation, and frustration of contractual expectations. 